\title{
Capability of some agricultural wastes for removing some heavy metals from polluted water stocked in combination with Nile tilapia, Oreochromis niloticus (L.)
}

\author{
Mohsen Abdel-Tawwab • Gamal O. El-Sayed • Sherien H. H. Shady
}

Received: 14 January 2017/Accepted: 18 April 2017/Published online: 28 April 2017

(C) The Author(s) 2017. This article is an open access publication

\begin{abstract}
Heavy metal (HM) pollution is one of the major problems that adversely affect the aquatic ecosystem and inhabiting biota. Heavy metals adsorption by low-cost adsorbents is one of the techniques used for HM removing from polluted water. In the present study, agricultural wastes (AW), i.e., rice straw, sugarcane bagasse, and maize stalks, were washed with distilled water, dried in a dry-oven, cut into small pieces $(<0.5 \mathrm{~cm}$ long), and immersed at $1.0 \mathrm{~g} / \mathrm{L}$ in aquaria containing synthetic mixture of lead $(\mathrm{Pb})$, cadmium $(\mathrm{Cd})$, copper $(\mathrm{Cu})$, and zinc $(\mathrm{Zn})$. Nile tilapia, Oreochromis niloticus (L.), fingerlings (25.2 $\pm 0.88 \mathrm{~g})$ were stocked at a density of ten fish per 100-L aquarium for $72 \mathrm{~h}$, during which fish were fed on a fish diet containing $25 \%$ crude protein ad libitum twice daily. Samples of water, AW, and fish were collected at different times to determine HM concentrations. The HM removal from polluted water was depending on the type of the metal ions, AW, and the contact time. However, HM concentrations in aquaria waters of all AW treatments decreased significantly by increasing contact time up to $24 \mathrm{~h}$ after which their concentrations were almost the same. Concentrations of waterborne $\mathrm{Pb}, \mathrm{Cd}, \mathrm{Cu}$, and $\mathrm{Zn}$ in $\mathrm{AW}$-containing aquaria were significantly lower than those of AW-free aquaria. The presence of any AW reduced significantly HM concentrations. In AW-free aquaria, HM-exposed fish accumulated more HM in their body than those reared in AWcontaining aquaria. The results of this experiment showed that all AW had the capability to remove HM levels from the polluted water and reduce their bioaccumulation in fish body. However, rice straw was the more efficient adsorbent for all metals.
\end{abstract}

Keywords Nile tilapia $\cdot$ Agricultural wastes $\cdot$ Rice straw $\cdot$ Maize stalks $\cdot$ Sugarcane bagasse $\cdot$ Heavy metals . Bioaccumulation

\section{Introduction}

Heavy metal (HM) pollution is spreading throughout the world due to the expansion of industrial activities and they easily reach the aquatic ecosystem. Unfortunately, HM are non-biodegradable and could deteriorate fish growth and health (Fazio et al. 2014; Savorelli et al. 2016; Abdel-Tawwab 2016; Abdel-Tawwab et al.

M. Abdel-Tawwab (ه) - S. H. H. Shady

Department of Fish Biology and Ecology, Central Laboratory for Aquaculture Research, Abbassa, Abo-Hammad, Sharqia,

Egypt

e-mail: Mohsentawwab@gmail.com; Mohsen_tawwab@yahoo.com

G. O. El-Sayed

Chemistry Department, Faculty of Science, Benha University, Benha, Egypt 
2013, 2016). Thus, scientific methods for HM removal and/or detoxification are essential to improve the health of the fish inhabiting HM-stressed environment. One of these methods is the use of feed supplements that could adsorb HM and/or facilitate their release out of fish body and subsequently could improve fish health (Abdel-Tawwab 2015; Abdel-Tawwab et al. 2015, 2017a, 2017b). Many other treatment technologies such as adsorption have been developed to remove HM from polluted water.

Adsorption is generally known to be one of the most effective techniques for HM removal from wastewater (Benhima et al. 2008; Zafar et al. 2007; Gupta and Babu 2009; Mosa et al. 2011; Chiban et al. 2012; WitekKrowiak and Reddy 2013). Considerable attention has been paid to the development of effective and low-cost adsorbents. Thus, studies have been done on the use of AW as alternative biosorbants for HM removal from the aqueous effluents (Tarley and Arruda 2004; Mohan and Pittman 2006; Karnitz Júnior et al. 2010; Dos Santos et al. 2011; Chiban et al. 2012).

Nile tilapia, Oreochromis niloticus (L.), is one of the most known freshwater fish species in Egypt and worldwide due to its good growth and high-value market. This fish inhabits different aquatic ecosystems, which may be HM-polluted. On the other hand, some countries use wastewater in fish farming and polluted water may enter the fish farms (Easa et al. 1995; Shereif and Mancy 1995; Shereif et al. 1995). The HM pollution definitely deteriorates fish health and subsequently human health if the fish are consumed. Hence, a low-cost method for HM removal is essential to improve the health of aquatic ecosystem and subsequently the health of the farmed fish. Therefore, the present study was conducted to investigate the capability of rice straw, sugarcane bagasse, and maize stalks to remove HM from the polluted water and reduce their bioaccumulation in Nile tilapia.

\section{Materials and methods}

Preparation of the adsorbents

Rice straw, sugarcane bagasse, and maize stalks were collected from a local area (Abbassa, Abo-Hammad, Sharqia, Egypt). They were washed with distilled water many times, dried in a dry-oven (GCA, model 18EM, Precision Scientific group, Chicago, Illinois, USA) at $85{ }^{\circ} \mathrm{C}$ until constant weight, and cut into small pieces $(<0.5 \mathrm{~cm}$ long). Afterward, these wastes were used without any pre-treatment as adsorbents for HM.

Preparation of synthetic mixture of heavy metals

Several wastewater samples were collected randomly from Saft-El-Henna drainage $(10 \mathrm{~km}$ North-East Zagazig city, Sharqia, Egypt), stored in polyethylene bottles, decanted, and filtered on Whatman paper $(0.45 \mathrm{~mm}$ porosity). Concentrations of lead $(\mathrm{Pb})$, cadmium $(\mathrm{Cd})$, copper $(\mathrm{Cu})$, and zinc $(\mathrm{Zn})$ were determined as described. Synthetic mixtures of $\mathrm{HM}$, containing the same concentrations as in the drainage samples, were prepared using lead nitrate $\left(\mathrm{Pb}\left(\mathrm{NO}_{3}\right)_{2}\right)$, cadmium chloride $\left(\mathrm{CdCl}_{2} \cdot 2.5 \mathrm{H}_{2} \mathrm{O}\right)$, zinc sulfate $\left(\mathrm{ZnSO}_{4}\right)$, copper sulfate $\left(\mathrm{CuSO}_{4} \cdot 5 \mathrm{H}_{2} \mathrm{O}\right.$; Merck \& Co Inc., Kenilworth, NJ, USA).

Fish rearing and adsorption study

This study was based on a $4 \times 6$ factorial design with four adsorbents (control, rice straw, sugarcane bagasse, and maize stalks) and six contact times $(0,3,6,24,48$, and 72 h) in triplicates. Nile tilapia, O. niloticus (L.), fingerlings were obtained from the nursery ponds of the Central Laboratory for Aquaculture Research (CLAR), Abbassa, Abo-Hammad, Sharqia, Egypt. Fish were transferred to the wet laboratory and kept in an indoor fiberglass tank for 2 weeks for adaptation to the laboratory conditions where light-dark photoperiod cycle was maintained at $12-12 \mathrm{~h}$ using fluorescent tubes as a light source. During the adaptation period and the experimental running, fish were fed on a fish diet containing $25 \%$ crude protein as used by Abdel-Tawwab (2016) ad libitum twice daily at 9:00 and 14:00 h. The synthetic HM mixture was added to each 100-L aquarium and vigorously stirred. Then, fish $(25.2 \pm 0.88 \mathrm{~g})$ were distributed into aquaria at a density of 10 fish per aquarium. Each aquarium was supplied with compressed air via air-stones using aquarium's air pump. 
Each AW was kept in a net $(<0.5-\mathrm{mm}$ pore) and inserted in each corresponding aquarium at $1.0 \mathrm{~g} / \mathrm{L}$. At each contact time, samples from aquarium's water, AW, and whole-fish body were taken for HM determination.

Water quality parameters

Water samples were collected at each contact time from each aquarium to monitor different water quality parameters. Water temperature and dissolved oxygen were measured in site using a portable oxygen meter (Jenway, London, UK). The pH was measured using a pH-meter (Digital Mini-pH Meter, model 55, Fisher Scientific, Denver, CO, USA). The unionized ammonia $\left(\mathrm{NH}_{3}\right)$ was measured using Multi-parameters Ion Analyzer (HANNA Instruments, Rhode Island, USA). Total alkalinity and total hardness were determined by titration according to Boyd (1984).

Heavy metals residue

For measuring HM concentrations in water, 1-L water sample was filtered via $0.8 \mu \mathrm{m}$ Millipore acetylcellulose filter paper (Millipore, Bedford, MA, USA), digested with $10 \mathrm{ml}$ concentrated $\mathrm{H}_{2} \mathrm{SO}_{4}$ on a hot plate at $70{ }^{\circ} \mathrm{C}$, concentrated to $50 \mathrm{ml}$, and transferred to a volumetric flask. Samples were adjusted up to $100 \mathrm{ml}$ with redistilled water.

For measuring HM concentrations in AW and whole-fish body, a $1.0-\mathrm{g}$ sample was oven-dried at $85{ }^{\circ} \mathrm{C}$ until constant weight and ashed in a muffle furnace (Thermolyne Corporation, Dubuque, Iowa, USA) at $550{ }^{\circ} \mathrm{C}$ for $6 \mathrm{~h}$. Ash was digested with $5 \mathrm{ml}$ concentrated $\mathrm{H}_{2} \mathrm{SO}_{4}$ and gradually kept at $130{ }^{\circ} \mathrm{C}$ on a hot plate until complete dryness. Then, the digests were diluted with $2 \mathrm{~N} \mathrm{HCl}$ to a constant volume. Heavy metal concentrations were determined by using an atomic absorption spectrophotometer (Thermo 6600, Thermo Electron Corporation, Cambridge, UK), which was calibrated using standard solutions.

\section{Statistical analysis}

The obtained data were subjected to two-way ANOVA to evaluate effects of agricultural wastes and contact time as factors. Differences between means were tested at the 5\% probability level using Duncan test. All the statistical analyses were performed using SPSS program version 20 (SPSS, Richmond, VA, USA) as described by Dytham (1999).

\section{Results and discussion}

Water quality parameters (Table 1) did not show significant differences among the different treatments $(P>0.05)$ and they were within the acceptable ranges for fish culture (Boyd 1984). The metal concentrations used in the present study were $58.4 \mu \mathrm{g} / \mathrm{L}, 1.31 \mathrm{mg} / \mathrm{L}, 22.15 \mu \mathrm{g} / \mathrm{L}$, and $2.72 \mathrm{mg} / \mathrm{L}$ for $\mathrm{Pb}, \mathrm{Cd}, \mathrm{Cu}$, and $\mathrm{Zn}$, respectively (Table 2). Only, Cd concentration exceeded the permissible limits (USEPA 1986; WHO 1989).

Metal concentrations in aquaria's water were significantly affected by AW, contact time, and their interaction $(P<0.05$; Table 2$)$. In addition, concentrations of waterborne $\mathrm{Pb}, \mathrm{Cd}, \mathrm{Cu}$, and $\mathrm{Zn}$ in $\mathrm{AW}$-containing

Table 1 Changes in physico-chemical parameters of aquaria's water stocked with different agricultural wastes in combination with Nile tilapia exposed to synthetic heavy metals mixture for different contact times

\begin{tabular}{lcccccc}
\hline & $3 \mathrm{~h}$ & $6 \mathrm{~h}$ & $24 \mathrm{~h}$ & $48 \mathrm{~h}$ & $72 \mathrm{~h}$ & $P$ value \\
\hline Water temperature $\left({ }^{\circ} \mathrm{C}\right)$ & $26.4 \pm 0.22$ & $26.8 \pm 0.09$ & $26.6 \pm 0.06$ & $26.7 \pm 0.22$ & $26.6 \pm 0.13$ & 0.192 \\
Dissolved oxygen $(\mathrm{mg} / \mathrm{L})$ & $5.8 \pm 0.11$ & $5.9 \pm 0.12$ & $5.7 \pm 0.12$ & $5.9 \pm 0.09$ & $5.8 \pm 0.14$ & 0.530 \\
$\mathrm{pH}$ & $7.65 \pm 0.022$ & $7.68 \pm 0.031$ & $7.68 \pm 0.054$ & $7.68 \pm 0.031$ & $7.67 \pm 0.021$ & 0.081 \\
Unionized ammonia $(\mathrm{mg} / \mathrm{L})$ & $0.55 \pm 0.022$ & $0.54 \pm 0.016$ & $0.56 \pm 0.025$ & $0.53 \pm 0.025$ & $0.59 \pm 0.015$ & 0.074 \\
Total alkalinity $(\mathrm{mg} / \mathrm{L})$ & $158.3 \pm 1.67$ & $160.0 \pm 2.58$ & $160.0 \pm 2.01$ & $160.0 \pm 2.88$ & $155.8 \pm 1.54$ & 0.371 \\
Total hardness $(\mathrm{mg} / \mathrm{L})$ & $244.2 \pm 4.91$ & $244.2 \pm 4.91$ & $253.3 \pm 3.08$ & $250.0 \pm 4.83$ & $249.2 \pm 2.71$ & 0.482 \\
\hline
\end{tabular}


Table 2 Concentrations of lead $(\mathrm{Pb})$, cadmium $(\mathrm{Cd})$, copper $(\mathrm{Cu})$, and zinc $(\mathrm{Zn})$ in aquaria's water stocked with different agricultural wastes in combination with Nile tilapia exposed to synthetic heavy metals mixture for different contact times

\begin{tabular}{|c|c|c|c|c|c|}
\hline Exposure time (h) & Wastes & Lead $(\mu \mathrm{g} / \mathrm{L})$ & Cadmium (mg/L) & Copper $(\mu \mathrm{g} / \mathrm{L})$ & Zinc $(\mathrm{mg} / \mathrm{L})$ \\
\hline & \multicolumn{5}{|l|}{ Control } \\
\hline 0 & & $56.5 \mathrm{a}$ & $1.12 \mathrm{a}$ & $21.45 \mathrm{a}$ & $2.22 \mathrm{a}$ \\
\hline 3 & & $38.9 \mathrm{~b}$ & $0.59 \mathrm{c}$ & $15.66 \mathrm{~b}$ & $0.70 \mathrm{~cd}$ \\
\hline 6 & & $33.7 \mathrm{~cd}$ & $0.51 \mathrm{~cd}$ & $12.18 \mathrm{~cd}$ & $0.61 \mathrm{de}$ \\
\hline 24 & & $29.6 \mathrm{e}$ & $0.45 \mathrm{def}$ & $12.00 \mathrm{de}$ & $0.51 \mathrm{efgh}$ \\
\hline 48 & & 27.3ef & $0.41 \mathrm{defg}$ & $10.95 \mathrm{de}$ & $0.49 \mathrm{efgh}$ \\
\hline \multirow[t]{2}{*}{72} & & $24.2 \mathrm{f}$ & $0.39 \mathrm{efgh}$ & $10.58 \mathrm{de}$ & 0.47fghi \\
\hline & \multicolumn{5}{|c|}{ Rice straw } \\
\hline 0 & & $56.5 \mathrm{a}$ & $1.12 \mathrm{a}$ & $21.45 \mathrm{a}$ & $2.22 \mathrm{a}$ \\
\hline 3 & & $37.1 \mathrm{bc}$ & $0.51 \mathrm{~cd}$ & 10.16def & $1.06 \mathrm{~b}$ \\
\hline 6 & & 27.0ef & $0.43 \mathrm{def}$ & 9.11efgh & $0.77 \mathrm{c}$ \\
\hline 24 & & $25.1 \mathrm{f}$ & $0.39 \mathrm{efgh}$ & 7.19ghi & $0.50 \mathrm{efgh}$ \\
\hline 48 & & $24.6 \mathrm{f}$ & $0.38 \mathrm{efgh}$ & 7.17ghi & $0.43 \mathrm{ghi}$ \\
\hline \multirow[t]{2}{*}{72} & & $24.1 \mathrm{f}$ & $0.34 \mathrm{gh}$ & $6.50 \mathrm{hi}$ & 0.40hij \\
\hline & \multicolumn{5}{|c|}{ Sugarcane bagasse } \\
\hline 0 & & $56.5 \mathrm{a}$ & $1.12 \mathrm{a}$ & $21.45 \mathrm{a}$ & $2.22 \mathrm{a}$ \\
\hline 3 & & $30.2 \mathrm{de}$ & $0.58 \mathrm{c}$ & $10.58 \mathrm{de}$ & 0.60def \\
\hline 6 & & $17.7 \mathrm{~g}$ & $0.58 \mathrm{c}$ & $6.54 \mathrm{hi}$ & $0.55 \mathrm{efg}$ \\
\hline 24 & & $15.2 \mathrm{gh}$ & $0.50 \mathrm{~cd}$ & $6.51 \mathrm{hi}$ & $0.52 \mathrm{efgh}$ \\
\hline 48 & & $15.1 \mathrm{gh}$ & $0.48 \mathrm{cde}$ & $5.92 \mathrm{i}$ & $0.51 \mathrm{efgh}$ \\
\hline \multirow[t]{2}{*}{72} & & $15.1 \mathrm{gh}$ & $0.48 \mathrm{cde}$ & $5.48 \mathrm{i}$ & $0.50 \mathrm{efgh}$ \\
\hline & \multicolumn{5}{|c|}{ Maize stalks } \\
\hline 0 & & $56.5 \mathrm{a}$ & $1.12 \mathrm{a}$ & $21.45 \mathrm{a}$ & $2.22 \mathrm{a}$ \\
\hline 3 & & 26.2ef & $0.69 b$ & $14.78 \mathrm{bc}$ & $0.78 \mathrm{c}$ \\
\hline 6 & & $16.6 \mathrm{~g}$ & $0.58 \mathrm{c}$ & $9.62 \mathrm{defg}$ & $0.36 \mathrm{ijk}$ \\
\hline 24 & & $14.2 \mathrm{gh}$ & $0.45 \mathrm{def}$ & 7.38fghi & $0.28 \mathrm{jkl}$ \\
\hline 48 & & $12.1 \mathrm{~h}$ & 0.35 fgh & $6.32 \mathrm{hi}$ & $0.26 \mathrm{kl}$ \\
\hline 72 & & $11.9 \mathrm{~h}$ & $0.29 \mathrm{~h}$ & $4.74 \mathrm{i}$ & 0.231 \\
\hline Pooled SE & & 1.769 & 0.031 & 0.668 & 0.079 \\
\hline Two-way ANOVA & & $P$ value & & & \\
\hline \multicolumn{2}{|c|}{ Agricultural wastes (AW) } & 0.0001 & 0.0001 & 0.0001 & 0.0001 \\
\hline \multicolumn{2}{|l|}{ Contact time } & 0.0001 & 0.0001 & 0.0001 & 0.0001 \\
\hline \multicolumn{2}{|l|}{$\mathrm{AW} \times$ contact time } & 0.0001 & 0.008 & 0.013 & 0.0001 \\
\hline
\end{tabular}

Means followed by the same letter are not significantly different

aquaria were significantly lower than those of AW-free aquaria. Moreover, metal concentrations in AW were significantly affected by AW, contact time, and their interaction $(P<0.05$; Table 3$)$. Concentrations of all tested metals in AW increased significantly by time up to $24-48 \mathrm{~h}$ after that their concentrations were approximately the same (Table 3). These results could be attributed to the availability of adsorbing site (surface functional groups) on the adsorbent surface. Additionally, AW may be fermented within days and subsequently their adsorption capacity was low. Similar results with rice straw were obtained by Swelam et al. (2016) who found that the $\mathrm{Cu}$ adsorption by straw rice increased significantly with increasing contact time and became almost constant for $\sim 3.5 \mathrm{~h}$.

All AW adsorbed metals, but rice straw, were the most efficient adsorbent for all metals. It is clear that metal removal was depending on the type of the metal ions, the adsorbent, and the contact time. Each AW contains many compounds, which have a variety of functional groups present in the binding process, for example carboxyl, amino, alcohol, and esters (Gupta and Ali 2000). These functional groups have the ability 
Table 3 Concentrations of lead, cadmium, copper, and zinc ( $\mathrm{mg} / \mathrm{g}$ dry weight) in different agricultural wastes stocked in combination with Nile tilapia exposed to synthetic heavy metals mixture for different contact times

\begin{tabular}{|c|c|c|c|c|c|}
\hline Exposure time (h) & Wastes & Lead & Cadmium & Copper & Zinc \\
\hline & Rice straw & & & & \\
\hline 0 & & $0.23 \mathrm{j}$ & $0.65 \mathrm{~g}$ & $0.28 \mathrm{f}$ & $1.32 \mathrm{~h}$ \\
\hline 3 & & $1.50 \mathrm{e}$ & $2.89 \mathrm{f}$ & $0.74 \mathrm{e}$ & $2.71 \mathrm{~g}$ \\
\hline 6 & & $2.41 \mathrm{c}$ & $6.91 \mathrm{e}$ & $1.28 \mathrm{~d}$ & $5.36 f$ \\
\hline 24 & & $3.04 \mathrm{~b}$ & $14.72 \mathrm{~d}$ & $1.64 b$ & $10.39 \mathrm{c}$ \\
\hline 48 & & $3.48 \mathrm{a}$ & $35.49 \mathrm{a}$ & $1.98 \mathrm{a}$ & $14.85 \mathrm{a}$ \\
\hline \multirow[t]{2}{*}{72} & & $3.64 \mathrm{a}$ & $35.68 \mathrm{a}$ & $2.07 \mathrm{a}$ & $15.31 \mathrm{a}$ \\
\hline & Sugarcane bagasse & & & & \\
\hline 0 & & $0.27 \mathrm{j}$ & $0.72 \mathrm{~g}$ & $0.26 f$ & $1.37 \mathrm{~h}$ \\
\hline 3 & & $0.87 \mathrm{~g}$ & $2.11 \mathrm{f}$ & $0.61 \mathrm{e}$ & $2.59 \mathrm{~g}$ \\
\hline 6 & & $0.94 \mathrm{fg}$ & $6.73 \mathrm{e}$ & $1.15 \mathrm{~d}$ & $5.45 \mathrm{f}$ \\
\hline 24 & & $1.94 \mathrm{~d}$ & 13.23 & $1.43 \mathrm{c}$ & $6.14 \mathrm{ef}$ \\
\hline 48 & & $2.48 \mathrm{c}$ & $21.66 \mathrm{c}$ & $1.48 \mathrm{c}$ & $7.02 \mathrm{de}$ \\
\hline \multirow[t]{2}{*}{72} & & $2.52 \mathrm{c}$ & $23.99 \mathrm{c}$ & $1.74 b$ & $8.10 \mathrm{~d}$ \\
\hline & Maize stalks & & & & \\
\hline 0 & & $0.15 \mathrm{j}$ & $0.37 \mathrm{~g}$ & $0.22 \mathrm{f}$ & $1.28 \mathrm{~h}$ \\
\hline 3 & & $0.42 \mathrm{i}$ & $2.30 \mathrm{f}$ & $0.68 \mathrm{e}$ & $2.98 \mathrm{~g}$ \\
\hline 6 & & $0.68 \mathrm{~h}$ & $6.07 \mathrm{e}$ & $1.19 \mathrm{~d}$ & $5.28 \mathrm{f}$ \\
\hline 24 & & $0.82 \mathrm{~g}$ & $13.66 \mathrm{~d}$ & $1.48 \mathrm{c}$ & $11.14 \mathrm{c}$ \\
\hline 48 & & $0.93 \mathrm{fg}$ & $26.22 b$ & $1.74 b$ & $13.78 \mathrm{bc}$ \\
\hline 72 & & $0.97 \mathrm{fg}$ & $29.61 b$ & $1.96 \mathrm{a}$ & $14.18 \mathrm{ab}$ \\
\hline Pooled SE & & 0.162 & 0.225 & 0.191 & 0.960 \\
\hline Two-way ANOVA & & $P$ value & & & \\
\hline Agricultural wastes (AW) & & 0.0001 & 0.0001 & 0.0001 & 0.0001 \\
\hline Contact time & & 0.0001 & 0.0001 & 0.0001 & 0.0001 \\
\hline $\mathrm{AW} \times$ contact time & & 0.0001 & 0.001 & 0.0001 & 0.0001 \\
\hline
\end{tabular}

Means followed by the same letter are not significantly different

to bind metal ions in solution or by donation of an electron pair from these groups to form metal complexes. Due to the differences in chemical compositions and functional groups of each AW used in the present study, the adsorption capability differs. Many researchers found a relationship between the presence of various functional groups and their complexation with metals during biosorption process (Tarley and Arruda 2004). The AW capacity for metal removal depends on many factors such as metallic elements, pretreatments of AW, and operating conditions; however, AW tended to prefer some metals more than others (Nguyen et al. 2013). Benaissa (2006) investigated the capacity of four inexpensive materials which are peels of peas, broad bean, medlar and fig leaves, to remove $\mathrm{Cd}$ from aqueous solutions; it was noted that the broad bean peel has the maximum adsorption capacity for $\mathrm{Cd}$.

In the present study, rice straw was more effective adsorbent than sugarcane bagasse and maize stalks. The higher adsorption capacity of rice straw is probably due to the presence of silanol $(\mathrm{SiOH})$ groups in its structure and more surface area (Fatemeh et al. 2008). In this regard, Osman et al. (2010) reported that rice hull showed highest efficiency in sequestering $\mathrm{Zn}, \mathrm{Cd}$, and iron among biosorbents investigated and the removal efficiencies by rice hull, sawdust, sugarcane bagasse, and wheat straw were 98.2, 96.9, 93.0, and $91.2 \%$, respectively. Additionally, the difference in AW capacity to adsorb metals could be attributed to the abundant availability of binding sites, which enhances the retention of metals onto AW surface (Marin-Rangel et al. 2012; Jiménez-Cedillo et al. 2013; Nguyen et al. 2013). Kelly-Vargas et al. (2012) reported that lemon peel and orange peel demonstrated adsorption capacities for $\mathrm{Cu}$ and $\mathrm{Pb}$ were 48 and 15\% higher than banana peel, respectively, and the Cd uptake by banana peel was higher than that of lemon peel and orange peel 82 and 57\%, respectively. On the other hand, Mosa et al. (2011) reported that the removal efficiency of metals 
decreased in the order of cotton stalks, maize stalks, and rice straw. They attributed highest removal by cotton stalks to its highest concentration of cellulose, hemicellulose, and lignin as compared to other crop-residues.

All AW adsorbents reduced significantly HM concentrations in whole-fish body $(P<0.05$; Table 4$)$. In $\mathrm{AW}$-free aquaria, HM-exposed fish accumulated more $\mathrm{HM}$ than those reared in AW-containing aquaria. These results suggest that $\mathrm{AW}$ immersion in aquaria stocked with Nile tilapia could reduce metal bioaccumulation in their body. It also noticed that metal concentrations in fish body were higher than those in polluted water. Concentration of $\mathrm{Pb}, \mathrm{Cd}, \mathrm{Cu}$, and $\mathrm{Zn}$ in whole-body of Nile tilapia 72-h post exposure in $\mathrm{AW}$-free aquaria were $0.714,5.47,1.309$, and $7.37 \mathrm{mg} / \mathrm{g}$ dry weight, respectively, (Table 4). However, $\mathrm{Pb}$ concentrations (0.267, 0.286, and $0.290 \mathrm{mg} / \mathrm{g}$ dry weight), Cd concentrations $(3.98,3.52$, and $3.58 \mathrm{mg} / \mathrm{g}$ dry weight), $\mathrm{Cu}$ concentrations $(0.284,0.262$, and $0.283 \mathrm{mg} / \mathrm{g}$ dry weight), and $\mathrm{Zn}$ concentration $(3.27,3.64$, and $3.13 \mathrm{mg} / \mathrm{g}$ dry weight) in fish body were approximately the same when fish were stocked with rice straw, sugarcane bagasse, and maize stalks for $72 \mathrm{~h}$, respectively.

Table 4 Concentrations of lead, cadmium, copper, and zinc (mg/g dry weight) in whole-body of Nile tilapia exposed to synthetic heavy metals mixture in combination with different agricultural wastes for different contact times

\begin{tabular}{|c|c|c|c|c|c|}
\hline Exposure time (h) & Wastes & Lead & Cadmium & Copper & Zinc \\
\hline & Control & & & & \\
\hline 0.0 & & $0.031 \mathrm{~g}$ & $1.67 \mathrm{e}$ & $0.082 \mathrm{~h}$ & $1.42 \mathrm{f}$ \\
\hline 3 & & $0.372 \mathrm{~d}$ & $3.41 \mathrm{c}$ & $0.412 \mathrm{~d}$ & $4.23 \mathrm{c}$ \\
\hline 6 & & $0.449 \mathrm{c}$ & $4.23 b$ & $0.617 \mathrm{c}$ & $5.62 \mathrm{~b}$ \\
\hline 24 & & $0.575 \mathrm{~b}$ & $4.84 \mathrm{ab}$ & $0.975 b$ & $6.39 \mathrm{ab}$ \\
\hline 48 & & $0.656 a b$ & $5.22 \mathrm{a}$ & $1.249 \mathrm{a}$ & $6.91 \mathrm{a}$ \\
\hline \multirow[t]{2}{*}{72} & & $0.714 \mathrm{a}$ & $5.47 \mathrm{a}$ & $1.309 \mathrm{a}$ & $7.37 \mathrm{a}$ \\
\hline & Rice straw & & & & \\
\hline 0.0 & & $0.031 \mathrm{~g}$ & $1.67 \mathrm{e}$ & $0.082 \mathrm{~h}$ & $1.42 \mathrm{f}$ \\
\hline 3 & & $0.112 \mathrm{f}$ & $1.98 \mathrm{de}$ & $0.102 \mathrm{~g}$ & $1.83 \mathrm{ef}$ \\
\hline 6 & & $0.175 \mathrm{ef}$ & $2.23 \mathrm{~d}$ & $0.161 \mathrm{fg}$ & $2.28 \mathrm{e}$ \\
\hline 24 & & $0.218 \mathrm{ef}$ & $2.84 \mathrm{~d}$ & $0.216 \mathrm{ef}$ & $2.73 \mathrm{de}$ \\
\hline 48 & & $0.251 \mathrm{ef}$ & $3.52 \mathrm{c}$ & $0.252 \mathrm{ef}$ & $3.13 \mathrm{~d}$ \\
\hline \multirow[t]{2}{*}{72} & & $0.267 \mathrm{ef}$ & $3.98 \mathrm{c}$ & $0.284 \mathrm{e}$ & $3.27 \mathrm{~d}$ \\
\hline & Sugarcane bagasse & & & & \\
\hline 0.0 & & $0.031 \mathrm{~g}$ & $1.67 \mathrm{e}$ & $0.082 \mathrm{~h}$ & $1.42 \mathrm{f}$ \\
\hline 3 & & $0.135 f$ & $1.72 \mathrm{e}$ & $0.125 \mathrm{~g}$ & $1.83 \mathrm{ef}$ \\
\hline 6 & & $0.190 \mathrm{ef}$ & $1.83 \mathrm{de}$ & $0.174 \mathrm{fg}$ & $2.24 \mathrm{e}$ \\
\hline 24 & & $0.231 \mathrm{ef}$ & $1.97 \mathrm{de}$ & $0.213 \mathrm{ef}$ & $2.83 \mathrm{de}$ \\
\hline 48 & & $0.263 \mathrm{ef}$ & $2.38 \mathrm{de}$ & $0.243 \mathrm{ef}$ & $3.18 \mathrm{~d}$ \\
\hline \multirow[t]{2}{*}{72} & & $0.286 \mathrm{e}$ & $2.86 \mathrm{~d}$ & $0.262 \mathrm{ef}$ & $3.64 d$ \\
\hline & Maize stalks & & & & \\
\hline 0.0 & & $0.031 \mathrm{~g}$ & $1.67 \mathrm{e}$ & $0.082 \mathrm{~h}$ & $1.42 \mathrm{f}$ \\
\hline 3 & & $0.113 f$ & $1.81 \mathrm{de}$ & $0.132 \mathrm{~g}$ & $1.78 \mathrm{ef}$ \\
\hline 6 & & $0.175 \mathrm{ef}$ & $2.31 \mathrm{~d}$ & $0.198 \mathrm{fg}$ & $2.10 \mathrm{e}$ \\
\hline 24 & & $0.228 \mathrm{ef}$ & $2.92 d$ & $0.237 \mathrm{ef}$ & $2.97 \mathrm{de}$ \\
\hline 48 & & $0.262 \mathrm{ef}$ & $3.46 \mathrm{c}$ & $0.261 \mathrm{ef}$ & $3.05 \mathrm{~d}$ \\
\hline 72 & & $0.290 \mathrm{e}$ & $3.58 \mathrm{c}$ & $0.283 \mathrm{e}$ & $3.13 \mathrm{~d}$ \\
\hline Pooled SE & & 0.854 & 0.449 & 0.659 & 1.519 \\
\hline Two-way ANOVA & & $P$ value & & & \\
\hline Agricultural wastes (AW) & & 0.0001 & 0.0001 & 0.0001 & 0.0001 \\
\hline Contact time & & 0.0001 & 0.0001 & 0.0001 & 0.0001 \\
\hline $\mathrm{AW} \times$ contact time & & 0.0001 & 0.0001 & 0.0001 & 0.0001 \\
\hline
\end{tabular}

Means followed by the same letter are not significantly different 
Metal concentrations in whole-fish body were higher than those of HM-polluted water. This is because fish accumulated more metals in their bodies. Similar results were obtained by Abdel-Tawwab et al. (2013, 2016). Khalil and Hussein (1997) reared Nile tilapia for 9 months in secondary effluents with $1.0 \mathrm{~Pb} \mathrm{mg} / \mathrm{L}$ and found that the concentration of $\mathrm{Pb}$ in fish flesh was tenfold higher than the food standard. It is also noticed that HM accumulation in fish body increased as contact time increased. Easa et al. (1995), Shereif et al. (1995) and Shereif and Mancy (1995) studied $\mathrm{Pb}, \mathrm{Cu}, \mathrm{Zn}$, and $\mathrm{Cd}$ in Nile tilapia reared in fishponds received wastewater. They found that HM concentrations in the fish increased by increasing the culture period.

\section{Conclusions}

Rice straw, sugarcane bagasse, and maize stalks are effective and cheap adsorbents for removal of $\mathrm{Pb}, \mathrm{Cd}, \mathrm{Cu}$, and $\mathrm{Zn}$ from polluted water. They also reduced HM bioaccumulation in fish body. Rice straw showed higher adsorption efficiency than the others.

Open Access This article is distributed under the terms of the Creative Commons Attribution 4.0 International License (http:// creativecommons.org/licenses/by/4.0/), which permits unrestricted use, distribution, and reproduction in any medium, provided you give appropriate credit to the original author(s) and the source, provide a link to the Creative Commons license, and indicate if changes were made.

\section{References}

Abdel-Tawwab M (2015) The use of American ginseng (Panax quinquefolium) in practical diets for Nile tilapia (Oreochromis niloticus): resistance to waterborne copper toxicity. Aquac Res 46:1001-1006

Abdel-Tawwab M (2016) Effect of feed availability on susceptibility of Nile tilapia, Oreochromis niloticus (L.) to environmental zinc toxicity: growth performance, biochemical response, and zinc bioaccumulation. Aquaculture 464:309-315

Abdel-Tawwab M, Mousaad MNM, Sharafeldin KM, Ismaiel NEM (2013) Changes in growth and biochemical status of common carp, Cyprinus carpio L. exposed to water-born zinc toxicity for different periods. Internat. Aquat Res 5:11 (1-9)

Abdel-Tawwab M, Sharafeldin KM, Mousaad MNM, Ismaiel NEM (2015) Coffee bean in common carp, Cyprinus carpio L. diets: effect on growth performance, biochemical status, and resistance to waterborne zinc toxicity. Aquaculture 448:207-213

Abdel-Tawwab M, El-Sayed GO, Shady SH (2016) Growth, biochemical variables, and zinc bioaccumulation in Nile tilapia, Oreochromis niloticus (L.) as affected by waterborne zinc toxicity and exposure period. Int Aquat Res 8:197-206

Abdel-Tawwab M, El-Sayed GO, Monier MN, Shady SH (2017a) Dietary EDTA supplementation improved growth performance, biochemical variables, antioxidant response, and resistance of Nile tilapia, Oreochromis niloticus (L.) to environmental heavy metals exposure. Aquaculture 473:478-486

Abdel-Tawwab M, Sharafeldin KM, Ismaiel NEM (2017b) Interactive effects of coffee bean supplementation and waterborne zinc toxicity on growth performance, biochemical variables, antioxidant activity and zinc bioaccumulation in whole body of common carp, Cyprinus carpio L. Aquac Nutr 2017:1-8. doi:10.1111/anu.12540

Benaissa H (2006) Screening of new sorbent materials for cadmium removal from aqueous solutions. Hazard Mater 132:189-195

Benhima H, Chiban M, Sinan F, Seta P, Persin M (2008) Removal of lead and cadmium ions from aqueous solution by adsorption onto micro-particles of dry plants. Colloids Surf. B: Biointerfaces 61:10-16

Boyd CE (1984) Water quality in warm fishponds. Auburn University Agriculture Experimental Station, Auburn

Chiban M, Soudani A, Sinan F, Persin M (2012) Wastewater treatment by batch adsorption method onto micro-particles of dried Withania frutescens plant as a new adsorbent. J Environ Manage 95:61-65

dos Santos WNL, Cavalcante DD, da Silva EGP, das Virgens CF, Dias FdS (2011) Biosorption of Pb(II) and Cd(II) ions by Agave sisalana (sisal fiber). Microchemical J 97:269-273

Dytham C (1999) Choosing and using statistics: a biologist's guide. Blackwell Science Ltd, London

Easa M, El-S Shereif MM, Shaaban AI, Mancy KH (1995) Public health implications of wastewater reuse for fish production. Water Sci Technol 32:145-152

Fatemeh A, Shariatmadari H, Mirghaffari N (2008) Modification of rice hull and sawdust sorptive characteristics for remove heavy metals from synthetic solutions and wastewater. J Hazard Mater 154:451-458

Fazio F, Piccione G, Tribulato K, Ferrantelli V, Giangrosso G, Arfuso F, Faggio C (2014) Bioaccumulation of heavy metals in blood and tissue of striped mullet in two Italian lakes. J Aquat Anim Health 26:278-284

Gupta VK, Ali I (2000) Utilization of bagasse fly ash (a sugar industry waste) for the removal of copper and zinc from wastewater. Sep Puri Technol 18:131-140

Gupta S, Babu BV (2009) Utilization of waste product (tamarind seeds) for the removal of Cr(VI) from aqueous solutions: equilibrium, kinetics, and regeneration studies. J Environ Manage 90:3013-3022

Jiménez-Cedillo MJ, Olguín MT, Fall C, Colin-Cruz A (2013) As(III) and As(V) sorption on iron-modified non-pyrolyzed and pyrolyzed biomass from Petroselinum crispum (parsley). J Environ Manage 117:242-252 
Karnitz Júnior O, Gurgel LVA, Gil LF (2010) Removal of Ca(II) and $\mathrm{Mg}$ (II) from aqueous single metal solutions by mercerized cellulose and mercerized sugarcane bagasse grafted with EDTA dianhydride (EDTAD). Carbohyd Polym 79:184-191

Kelly-Vargas K, Cerro-Lopez M, Reyna-Tellez S, Bandala ER, Sanchez-Salas JL (2012) Biosorption of heavy metals in polluted water, using different waste fruit cortex. Phys Chem Earth 37-39:26-29

Khalil MT, Hussein HA (1997) Use of waste water for aquaculture: an experimental field study at a sewage-treatment plant, Egypt. Aquacult Res 28:859-865

Marin-Rangel VM, Cortes-Martines R, Villanueva RAC, Garnica-Romo MG, Martinez-Flores HE (2012) As(V) biosorption in an aqueous solution using chemically treated lemon (Citrus aurantifolia swingle) residues. J Food Sci 71:10-14

Mohan D, Pittman CU Jr (2006) Activated carbons and low cost adsorbents for remediation of tri- and hexavalent chromium from water. J Hazard Mater 137(2):762-811

Mosa AA, El-Ghamry A, Trüby P (2011) Chemically modified crop residues as a low-cost technique for the removal of heavy metal ions from wastewater. Water Air Soil Pollut 217:637-647

Nguyen TAH, Ngo HH, Guo WS, Zhang J, Liang S, Yue QY, Li Q, Nguyen TV (2013) Applicability of agricultural waste and byproducts for adsorptive removal of heavy metals from wastewater. Biores Technol 148:574-585

Osman HE, Badwy RK, Ahmad HF (2010) Usage of some agricultural byproducts in the removal of some heavy metals from industrial wastewater. J Phytol 2:51-62

Savorelli F, Manfra L, Croppo M, Tornambè A, Palazzi D, Canepa S, Trentini PL, Cicero AM, Faggio C (2016) Fitness evaluation of Ruditapes philippinarum exposed to Ni. Biol Trace Elem Res. doi:10.1007/s12011-016-0885-y

Shereif M, Mancy K (1995) Organochlorine pesticides and heavy metals in fish reared in treated sewage effluents and fish grown in farms using polluted surface waters in Egypt. Water Sci Technol 32:153-161

Shereif M, El-S Easa M, El-Samra M, Mancy K (1995) A demonstration of wastewater treatment for reuse applications in fish production and irrigation in Suez. Egypt. Water Sci Technol 32:137-144

Swelam AA, Awad MB, Salem AMA, El-Feky AS (2016) Removal of copper ions from synthetic waste water using some agricultural wastes as a low-cost adsorbent. AOP J Environ Waste Manag 1:103-117

Tarley CRT, Arruda MAZ (2004) Biosorption of heavy metals using rice milling byproducts. Characterization and application for removal of metals from aqueous effluents. Chemosphere 54:987-995

USEPA (United States Environmental Protection Agency) (1986). Quality Criteria for Water. EPA 440/5-86-001

WHO (World Health Organization) (1989) Guidelines for drinking water quality, vol 1. Recommendations WHO, Geneva, p 19

Witek-Krowiak A, Reddy DHK (2013) Removal of microelemental $\mathrm{Cr}(\mathrm{III})$ and $\mathrm{Cu}(\mathrm{II})$ by using soybean meal waste: unusual isotherms and insights of binding mechanism. Bioresour Technol 127:350-357

Zafar MN, Nadeem R, Hanif MA (2007) Biosorption of nickel from protonated rice bran. J Hazard Mater 143:478-485 